\title{
The Sandhill Cranes of Big Grass Marsh
}

\author{
by J. B. Wright, Plumas, Manitoba
}

I saw cranes, as a small boy going to school, in the spring of 1888 . We lived about five miles west of the Big Grass Marsh where we sometimes pastured our cattle. A little creek touched the side of our homestead. This creek was called Crane Creek before we came to the district so cranes were here before the white man and we were the trespassers on their territory.

The Big Grass Miarsh, here in south central Manitoba, is about twenty miles from north to south and from four to six miles from elast to west. The water level in this area varies from year to year but always there are some shallow lakes in the lower spots. The higher spots are usually dry and here farmers have permits to cut hay. The west side of the Marsh is a community pasture which is fenced for catitle. Much of the Marsh is a Wildlife Preserve where hunting and trapping are prohibited. Sometimes the boundaries of the preserve and the pasture coincide but the preserve includes more of the Marsh. The preserve includes 58 sections and 11 half sections and all the road allowances in the areas. The preserve, therefore, includes more than 40,000 acres.

I have always been interested in all forms of wildlife. My observations cover a period of over 60 years as I worked about the farm, roamed over the country, herded caittle or hunted. Although, like other farmers, I do not like the damage done to the crops by birds I do like to have the refuge close by. I do like to see the birds and am glad to be in the only area in Manitoba where there is a considerable concentration of Sandhill Cranes. We also used to see a few Whooping Cranes in the spring in early days. We called them "White Cranes." I think the last I ever saw would be in the last half of the nineties.

Ducks, geese and cranes do some damage to crops although this year, 1960 , the damage was slight for the harvest was early. The birds fed in combined fields while the farmers were harvesting elsewhere. Mast of the damage, in any case, is on account of the manner of harvesting. Some birds have always fed in fields since crops were grown. They did little damage to sheaves or stooks, they mostly picked up what was loose on the ground-but now they tramp and defile the swaths as well as eating grain.

In the early days we would not see much of the Sandhill Cranes in summer, but a few flocks would come to the grain fields in harvest time. Some cranes nested in the Marsh and I once' saw a young one which had been captured by two brothers who had been haying in the Marsh. A Mr. Blacksitock told me that

\section{REFERENCES CITED}

Bailey, F. M. 1928. Binds of New Mexico; Washington, D.C.

Cooke, W. W. 1897. The birds of Colorado. State Agric. Coll. Bull. No. 37 (Tech. Ser. No. 2 ).

Cutler, B. D., and E. A. Pugh. 1959. Regional report (middle Pacific coast region). Aud. Field Notes, 13:216-319.

Dementiev, G. P. and N. A. Gladkov. 1951. Birds of the Soviet Union.

Harris, H. 1919. Birds of the Kansas City region, Kansas City, Missouri. From Trans. Acad. Soi. of St. Louis, Mo.: 213-371.

Ledingham, G. F. 1960. The Sandhill Crane problem. Blue Jay, 18:152-155.

MoLean. D. D. 1930. Spring observations on crames in Fresno County, California. Condor, 32:3-8.

Manning, T. H. E. O. Hohn; and A. H. MacPherson. 1956. The birds of Banks Island. Nati. Mus. Canada, Bull. .143.

Monson; G. 1950. Regional report (southwest region). Aud. Field Notes, 4:214-216.

1954. Regional Report (southwest region). Aud. Field Notes, 8:262-264.

1956. Regional report (southwest region). Aud. Field Notes, $10: 44-47 ; 271-274$

1958. Regional repont (southwest region). Aud. Field Notes, 12:298-301.

Munro, D. A. 1950. Ecomomic status of the Sandhill Cranes in Saskatchewan. Journ. Wildlife Manasement. 14:276-284.

Rand, A. L. 1944. Birds of the Alaska Highway in British Columbia. Can. Field-Nat., 58:111-125.

Smith, M. A.. 1958. Regional report (Cohoe, Alaska). Aud. Field Notes, 12:51-52.

1959. Regional report (Cohoe, Alaska). Aud. Field Notes, 13:55-57.

1960. Regional report (Cohoe, Alaska). Aud. Field Notes, $14: 63-65$.

Walkinshaw, L. H., 1949. The Sandhill Cranes. Cranbrook. Inst. Sci., Bull. 29.

Walkinshaw, L. H., W. P. Cottrille, and B. D. Cottrille. 1960. Southern Miahigan Sandhill Crane survey, 1952-1958. Jack Pine Warbler. 38:25-28. 
the cranies used to hatch round sloughs a little northeast of Keyes and that they just laid two eggs. I think the Cranes started feeding in the fields in larger numbers about 1930. The refuge serves as a real sanctuary from which the birds come morning and evening to feed in the fields. The closest fields are used first but as the fall hunting season begins the birds begin to go as much as ten miles from the refuge.

I think that it is great that we have this refuge, for we always have birds close by. Both farmers and urban people alike enjoy the pleasure and profit of being able to hunt in their own area. But even greater than the thrill of hunting is the pleasure of of seeing and hearing a flock of ducks feeding, those at the rear flying up to the front, now and then a green head raised to look for trouble and all the time the low quack-quack, quackquack; or a flock of Canada Geese or Sandhill Cranes. Those sharp eyes of theirs miss nothing.
There will be some damage to crops every fall in the Big Grass Marsh area. The Manitoba Government has experimented with feeding stations at the marsh's edge but the success of this has not been great and geese and cranes do noit use the stations. Last fall, 1960, the Manitoba Government with the help of the Canadian Wildlife Service studied the problem and helped troubled landowners to scare cranes from unharvested fields. This program will be continued during 1961 .

Farmers suffering damage should be paid for their loss but I would not like to see an open season on the Sandhill Crane. Even though there may be 10,000 each spring and fall in this area they could easily be wiped out by an open season, for they have, like a Whooping Crane, a very slow rate of increase. It was man that almost exterminated the Whooping Crane and I would not like to see this happen to the Sandhill.

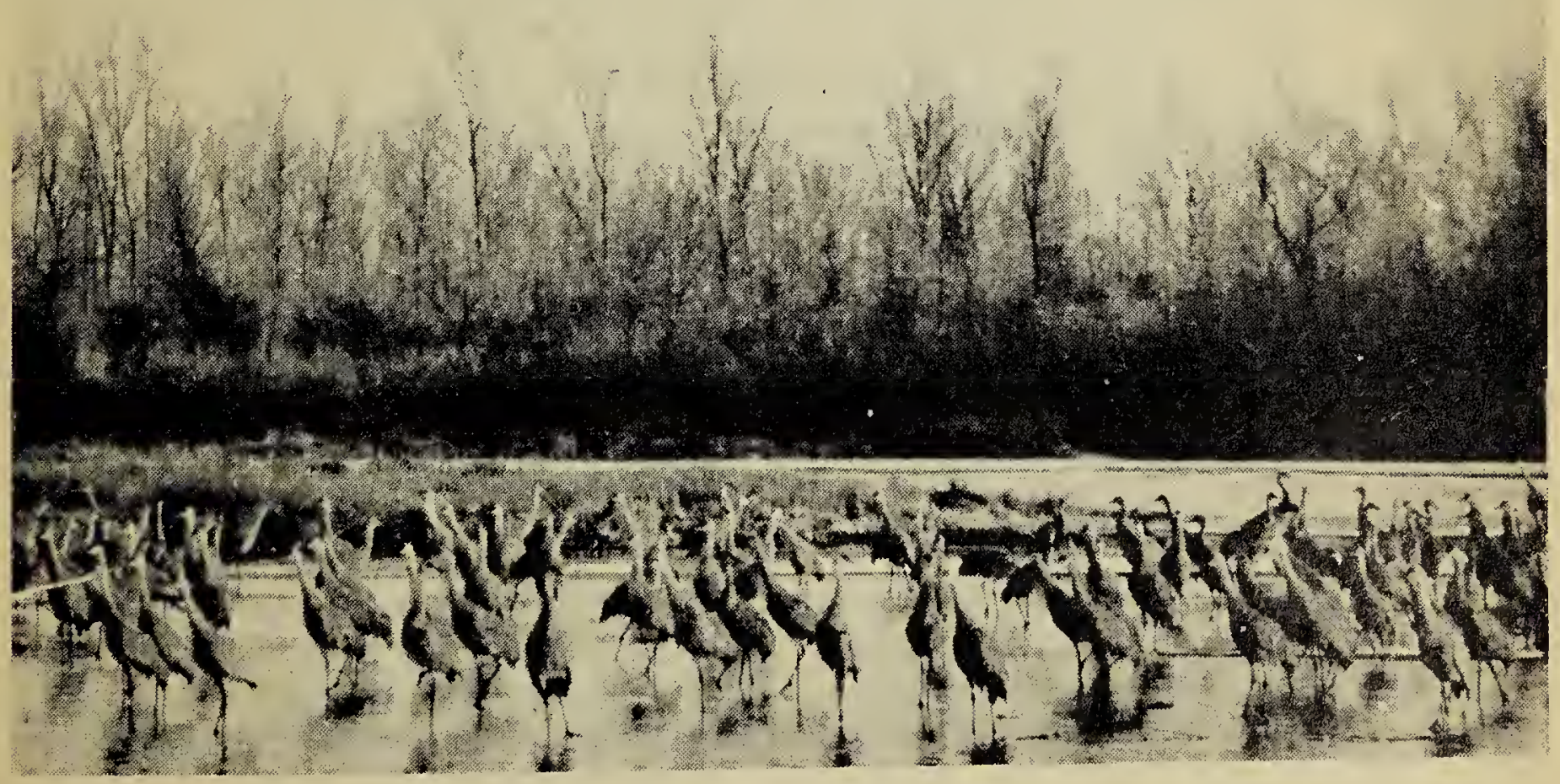

Part of a floak of 25,000 Sandhill Cranes on roost area along the Platte River, Nebraska, March 26, 1954. 